\title{
Kielten samankaltaisuus monikielisen suomalais-virolaisen vuorovaikutuksen resurssina
}

\author{
HANNA-ILONA H ÄRM ÄVAARA \\ Helsingin yliopisto
}

Tiivistelmä. Viro ja suomi ovat sukukieliä, joita ei yleensä pidetä keskenään vaivatta ymmärrettävinä. Suomalaisten ja virolaisten välisessä vuorovaikutuksessa kielten samankaltaisuus luo kuitenkin pohjan yhteisen ymmärryksen rakentamiselle. Tässä artikkelissa tarkastellaan sitä, miten viron ja suomen samankaltaisuutta käytetään resurssina sellaisessa suomalais-virolaisessa vuorovaikutuksessa, jota voi kutsua reseptiiviseksi monikielisyydeksi. Reseptiivisellä monikielisyydellä tarkoitetaan vuorovaikutusta, jossa käytetään pääasiassa kunkin osallistujan äidinkieltä ja jossa ei useimmiten ole käytössä erillistä lingua francaa. Tutkimuksen aineisto koostuu videoiduista monenkeskisistä arkikeskusteluista, joita analysoidaan keskustelunanalyysin keinoin. Tutkimuksessa osoitetaan, että vuorovaikutuksen virolaiset ja suomalaiset osallistujat luovat ryhmän yhteistä koodia yhdistämällä kielten aineksia toisiinsa hyödyntäen kontrastiivista tietämystään ääntämyksen, morfologian ja sanaston tasolla. Tutkimuksessa näytetään toteen myös se, että aina näin tuotetuilla kompromissimuodoilla ei pyritä (pelkästään) ymmärrettävyyden parantamiseen, vaan niitä voidaan käyttää esimerkiksi kielellä leikittelyyn ja monikielisen ryhmäidentiteetin luomiseen.

Avainsanat: reseptiivinen monikielisyys; keskustelunanalyysi; sukukielen ymmärtäminen; mukauttaminen; ryhmäidentiteetti 


\section{Johdanto}

Suomi ja viro ovat sukukieliä, joita usein pidetään kutkuttavan samankaltaisina mutta keskinäisen ymmärrettävyyden kannalta toisilleen liian etäisinä. Suomalaisten ja virolaisten välisessä vuorovaikutuksessa kielten samankaltaisuus voi kuitenkin toimia yhtenä yhteisen ymmärryksen rakennusaineista. Tarkastelen artikkelissani viron ja suomen samankaltaisuutta sellaisen suomalais-virolaisen vuorovaikutuksen resurssina, jota voi kutsua reseptiiviseksi monikielisyydeksi. Reseptiivisellä monikielisyydellä $(\mathrm{RM})^{1}$ tarkoitetaan vuorovaikutusta, jossa äidinkieleltään eritaustaiset osallistujat käyttävät eri kieliä (tyypillisesti äidinkieliään) ja ymmärtävät toisiaan pääasiassa ilman erillistä lingua francaa (Zeevaert \& ten Thije 2007; Rehbein ym. 2012). Ymmärtäminen voi perustua kielten samankaltaisuuteen, toisen kielen omaksumiseen tai kumpaankin (erilaisista RM-vuorovaikutuksen lajeista läheisten, kaukaisempien ja ei-sukukielten välillä sekä virosta ja suomesta RM-vuorovaikutuksen kielinä, ks. Härmävaara, tulossa).

Reseptiiviseen monikielisyyteen liittyviä ilmiöitä on tutkimuksissa lähestytty erilaisista teoreettisista ja metodologisista näkökulmista, muun muassa kielenoppimisen, kielisosiologian ja vuorovaikutuksen tutkimuksen lähtökohdista (ks. ten Thije \& Zeevaert 2007; ten Thije ym.

\footnotetext{
$1 \quad$ Kutsun aineistoni vuorovaikutusta reseptiiviseksi monikielisyydeksi, vaikka vuorovaikutustapaa kuvaamaan on hiljattain (Rehbein ym. 2012) muotoutunut uusi käsite, lingua receptiva (LaRa). LaRa on tutkimukseni kannalta ongelmallinen käsite kahdesta syystä. Ensinnäkin se sisältää vuorovaikutuskäsityksen, joka on liian kapea kuvaamaan aineistoni arkivuorovaikutusta. LaRa sisältää vahvan puhuja-kuulijadikotomian, ja ymmärtäminen käsitetään puhujan ohjailemaksi prosessiksi, jonka tuloksena kuulijan on tarkoitus pystyä rekonstruoimaan puhujan aikoma merkitys ja puhetoiminto (engl. speaker's plan). Toisekseen LaRa nähdään selkeästi omana vuorovaikutuksen tapanaan, joka kontrastoituu lingua francaan ja muihin monikielisen vuorovaikutuksen tapoihin, kuten L2:n puhumiseen. Arkikeskusteluista koostuvassa aineistossani erilaisia vuorovaikutuksen tapoja käytetään kuitenkin rinnan ja sekaisin, ja yhteistä kaikelle aineiston vuorovaikutukselle on se, että se osaltaan perustuu (reseptiiviseen) sukukielen ymmärtämiseen. Ks. tarkemmin Härmävaara (tulossa).
} 
2012; tutkimuksen historiasta ks. Braunmüller \& Zeevaert 2001; Bezooijen \& Gooskens 2007: 250; myös Kaivapalu \& Muikku-Werner 2010). 2000-luvulla RM-tutkimus monine näkökulmineen on vakiintunut osaksi monikielisyystutkimuksen kenttää, ja myös viroa ja suomea on alettu tutkia RM-vuorovaikutuksen kielinä. Verschik (2012) on tarkastellut virolaisten myyjien ja heidän suomalaisten asiakkaidensa välistä vuorovaikutusta kontaktilingvistiikan näkökulmasta, ja Kaivapalu ja Muikku-Werner (2010) ovat alkaneet selvittää kirjallisin testein, miten sukukieltä ymmärretään oman äidinkielen pohjalta ja miten kielten samankaltaisuuksia havaitaan.

Tämä artikkeli on osa väitöstutkimusta, jossa tarkastelen reseptiivistä monikielisyyttä ja sen edellytyksiä suomalaisen osakunnan ja sen virolaisen ystävyyskorporaation jäsenten muodostamassa sosiaalisessa verkostossa. Kiinnostavaksi tutkimuskohteeksi tämän nuorten akateemisten ihmisten muodostaman yhteisön tekee järjestöjen välinen, 1930-luvulla solmittu ystävyyssopimus, jossa virallisen viestinnän kieliksi määritellään kunkin puhujan äidinkieli. RM tai edes jommankumman sukukielen käyttö ei kuitenkaan ole tutkimani yhteisön jäsenille itsestään selvä valinta. Usein epävirallisen seurustelun kielenä käytetään englantia, joka toimii tutkittavan yhteisön jäsenten lingua francana. Tässä artikkelissa keskityn vuorovaikutukseen, jossa hyödynnetään pääasiassa suomen ja viron tarjoamia kielellisiä resursseja.

Tarkastelen tässä artikkelissa sellaista monenkeskistä virolaissuomalaista vuorovaikutusta, jonka osallistujat osaavat toista kieltä eri määriä eli joilla on erilainen pääsy vuorovaikutuksessa käytettäviin sukukieliin. Suurimmalla osalla osallistujista (yht. 35 informanttia) ei ole aktiivista toisen kielen taitoa. Esitän analyysini yhteydessä tiedot kunkin vuorovaikutustilanteeseen osallistuvan henkilön toisen kielen taidosta. Aineistonani käytän vapaamuotoisista illanvietoista vuosina 2010 ja 2011 kerättyä vuorovaikutusta (yht. 12 tuntia). Aineistossa vuorovaikutuksen kielet (pääasiassa suomi ja viro) valikoituvat vapaasti, eikä RM-periaatetta pyritä noudattamaan. Litteraateissa suomalaiset osallistujat on merkitty $s$-kirjaimella ja virolaiset $v$-kirjaimella alkavin 
nimin. Koodinimi Sarita viittaa tutkijaan, joka on yksi tarkasteltavan yhteisön jäsenistä. Tutkimusotteeni onkin etnografinen, ja metodinani käytän keskustelunanalyysia sekä kielten kontrastointia.

Artikkeli on jatkoa tutkimukselle (Härmävaara, tulossa), jossa annan yleiskuvan tarkastellun aineiston vuorovaikutuksesta. Tutkimuksessa osoitan, ettei osallistuminen kummalla kielellä tahansa välttämättä aiheuta vuorovaikutuksen ongelmia ja että kielten samankaltaiset ainekset muodostavat yhden yhteisen ymmärryksen rakentamisen resursseista. Toisaalta havaitsin, etteivät osallistujat pidä sukukielen ymmärtämistä itsestäänselvyytenä vaan he orientoituvat vuorovaikutukseen potentiaalisesti ongelmallisena niille, jotka eivät hallitse meneillään olevan toiminnan kieltä. Tämä näkyy vuorovaikutuksessa muun muassa keinoina (esim. erilaiset kääntämistoiminnot), joilla kaikkien mahdollisuus osallistua pyritään varmistamaan. Havaintojeni mukaan kumpaakin kieltä osaavien osallistujien läsnäolo ja asettuminen kielenvälittäjän rooliin usein mahdollistavat RM-vuorovaikutuksen.

Oletan, että kielten sukulaisuus muodostaa pohjan yhteisen ymmärryksen rakentumiselle mutta ymmärrettävyyttä pyritään aktiivisesti varmistamaan osallistujien yhteisissä monikielisissä toiminnoissa. Kielten keskinäinen ymmärrettävyys onkin viime kädessä vuorovaikutuksen ominaisuus (ks. myös Rehbein ym. 2012). Tässä artikkelissa analysoin tarkemmin sellaisia toimintoja, joissa yhteistä ymmärrystä rakennetaan sukukielten (oletettua) samankaltaisuutta hyödyntäen. Pyrin analyysissani vastaamaan seuraaviin kysymyksiin: Miten kielten samankaltaisuutta ja niiden yhteisiä aineksia käytetään kaikille osallistujille ymmärrettävien ilmausten rakentamiseen? Mitä eri kielten aineksia yhdistelevillä kompromissirakenteilla tehdään vuorovaikutuksessa, ja miten ne vaikuttavat yhteisen ymmärtämisen syntyyn? 


\section{Kielten samankaltaisuus RM-vuorovaikutuksen resurssina}

RM-tutkimuksen juuret ovat läheisten sukukielten puhujien välisen vuorovaikutuksen tarkastelussa, vaikka nykyisin tutkimuksen kohteena on myös ei-sukukielten puhujien välinen RM (engl. inherent ja acquired RM, ks. Bahtina \& ten Thije 2012; Verschik 2012). Sukukielten puhujien välisessä RM-vuorovaikutuksessa perusolettamuksena on se, että kielten samankaltaisuus muodostaa pohjan yhteisen ymmärtämisen rakentumiselle. Mahdollisuus tarjota omaa äidinkieltään toisen kielen puhujien ymmärrettäväksi onkin RM-vuorovaikutuksen keskeisin kielten samankaltaisuuteen nojaava resurssi.

Skandinaavisten kielten puhujien välistä RM-vuorovaikutusta tutkineen Börestam Uhlmanin (1994: 90) mukaan hänen tarkastelemassaan vuorovaikutuksessa puhujien oma äidinkieli on selvästi yleisin kielivalinta ja kunkin osallistujan skandinaavisen äidinkielen käyttö "muodostaa laajimman pohjan ymmärtämiselle". Kuten olen edellä todennut, tämän voi katsoa aineistoni perusteella olevan suomalaisten ja virolaisten välisessä vuorovaikutuksessa totta vain osittain. Kielten samankaltaisuus muodostaa kuitenkin pohjan paitsi yhteisen ymmärryksen rakentumiselle myös sille oletukselle, että omaa kieltä muokkaamalla, kontrastiiviseen tietämykseen tai toisen kielen tuntemukseen perustuen, voi tuottaa toisen kielen puhujille ymmärrettäviä ilmauksia.

Sukukielten samankaltaisuutta RM-vuorovaikutuksen resurssina onkin tarkasteltu tutkimalla paitsi sitä, miten sukukieltä ymmärretään oman äidinkielen pohjalta, myös sitä, miten osallistujat tekevät puheensa toisenkielisille vastaanottajille ymmärrettävämmäksi yhdistämällä puheessaan sukukielten aineksia toisiinsa. Koska RM-vuorovaikutus tapahtuu pääasiassa kunkin osallistujan äidinkielellä, kielten ainesten yhdistämistä on käsitelty lähinnä oman kielen piirteiden muokkaamisena puhekumppanin kieltä vastaavammaksi (Rehbein ym. 2012: 249-250). RM-tutkimuksessa ilmiöstä käytetään nimitystä mukauttaminen (engl. accommodation), ja tutkimuksen lähtökohdat ovat 
akkommodaatioteoriassa (ks. Giles ym. 1991). Mukauttamiseen on erityisesti kiinnitetty huomiota tarkasteltaessa skandinaavisten kielten puhujien välistä vuorovaikutusta; nämä kielethän ovat keskenään läheisempiä kuin viro ja suomi. Börestam Uhlman (1994) ja Braunmüller (2002) ovat tutkineet, millaisin leksikaalisin, morfologisin ja fonologisin keinoin heidän skandinaaviset informanttinsa pyrkivät mukauttamaan äidinkieltään sellaiseksi, mitä he olettavat puhekumppaneidensa ymmärtävän äidinkielensä pohjalta parhaiten.

Oletettu ymmärrettävyys ei kuitenkaan aina vastaa todellista ymmärrettävyyttä, vaan Börestam Uhlmanin keskustelunanalyyttinen tutkimus paljastaa, että erilaiset kompromissimuodot voivat toimia sekä ymmärtämisen ongelman ratkaisijana että ongelman lähteenä (Börestam Uhlman 1994: 110-115; ks. myös Braunmüller 2002, jossa mukauttamista tarkastellaan "onnistuneena ja epäonnistuneena”). Tarkastelenkin analyysissani myös sitä, miten kompromissirakenteet vaikuttavat ymmärtämisen syntyyn ja mitä niillä vuorovaikutuksessa tehdään. Luvuissa 3, 4 ja 5 kuvaan erilaisia aineistossani esiintyviä tapoja käyttää kielten samankaltaisuutta vuorovaikutuksen resurssina. Tarkasteluni etenee oman äidinkielen vähäisestä äänteellisestä mukauttamisesta kohti laajempaa kielten rakenteellisen samankaltaisuuden hyödyntämistä ja leksikaalisen tason ilmiöitä. Usein eri ilmiöt kuitenkin kietoutuvat vuorovaikutuksessa yhteen ja ovat rajoiltaan häilyviä.

\section{3. Ääntäminen ja äännevastaavuuksien hyödyntäminen}

Skandinaavisten kielten puhujien välistä RM-vuorovaikutusta koskevissa tutkimuksissa kielellisen mukauttamisen on havaittu koskevan pääasiassa ääntämistä ja sanastotason ilmiöitä (Börestam Uhlman 1994: 92-95; Braunmüller 2002). Sekä Börestam Uhlman että Braunmüller tarkastelevat leksikaalisia elementtejä analyysinsa perusyksikköinä, ja heidän havaintonsa koskevatkin pääasiassa sitä, miten sukukieleen kuuluvia sanoja käytetään muuten äidinkielisessä puheessa ja miten kaikkien ymmärrettävissä olevaa sanastoa luodaan kielten aineksia yhdistämällä. 
Verschik (2012: 278) havaitsi oman kielen fonologisten piirteiden muokkaamisen olevan keino tuottaa toista kieltä lähentyviä kompromissimuotoja myös virolaisten ja suomalaisten välisessä vuorovaikutuksessa. Hän listaa virolaisten käyttämiksi fonologisiksi keinoiksi suomenkielisten sanojen tuottamisen ilman vokaaliharmoniaa sekä äännevastaavuuksien hyödyntämisen esimerkiksi muokkaamalla vironkielisestä ensitavun pitkän vokaalin sisältävästä sanavartalosta suomenkielisen ääntämällä pitkän vokaalin suomen mallin mukaan diftongiutuneena. Kuten Verschik (2012: 278-279) huomauttaa, usein on kuitenkin vaikea tietää, onko kyseessä puhujan oman äidinkielen pohjalta tuotettu kompromissimuoto vai aito yritys puhua toista kieltä (ks. myös Härmävaara, tulossa).

Pääpiirteiltään suomen ja viron fonologiset järjestelmät ovat melko samanlaiset, mutta niissä on myös eroja (ks. Härmävaara 2009: 14-22 kielten äännejärjestelmien vertailusta). Erityisesti prosodian erilaisuus vaikuttaa olevan helposti havaittavissa, ja usein puhe tutkimassani yhteisössä kääntyykin siihen, miten hauskalta toinen kieli kuulostaa (vrt. Junttila 2006). Käsitystä toisen kielen prosodiasta sekä tietoa äännevastaavuuksista käytetään aineistossani myös keinona lähentää kieliä toisiinsa. Esimerkissä (1) suomalainen Santtu, joka ilmoittaa ymmärtävänsä virosta "yksittäisiä lauseita" $(2)^{2}$, muokkaa suomenkielistä puhettaan viroa vastaavammaksi vironmukaisella ääntämyksellä sekä loppuheitolla. Keskusteluun osallistuvat myös virolaiset Villem (3), Valle (2) ja Vaano (5) sekä suomalaiset Salla (2), Samuli (2), Sampo (1) ja Saimi (2). Litteraateissa tarkastellun ilmiön kannalta keskeiset vuorot on lihavoitu.

\footnotetext{
2 Pyysin informantteja arvoimaan, miten hyvin he ymmärtävät toista kieltä asteikolla $0-5$, jossa 0 = en lainkaan, 1 = ymmärrän yksittäisiä sanoja, 2 = ymmärrän yksittäisiä lauseita, 3 =ymmärrän helpommista aiheista suurin piirtein sanotun/kirjoitetun keskeisen sisällön, 4 = ymmärrän lähes aina sanotun/kirjoitetun keskeisen sisällön ja 5 = ymmärrän lähes kaiken.
} 
$(1)^{3}$

01 Villem: ööö kui (.) mitu korda: te olete Eestis käinud varem.

02 Salla: kuinka monta kertaa me ollaan käyty [v- vi- Virossa

03 Valle:

$[(($ nyökkäilee $))$

04 Villem: joo

05

06 Salla: $\quad$ vaikka $\uparrow$ kuinka monta (.) lapsesta asti

07

08 Salla: $>$ lomalla $<$

09

10 Samuli: mä oon tänä vuonna kuus kertaa nyt

11

12 Sampo: mm heh heh heh

13 Salla: 个joka [vuas

14 Santtu: [mä oisin kans jotain (0.8) vịis kertaa vaa.

15 Saimi: [个monta.

16 Sampo: [yhteensä [vai

17 Saimi: [vaik kuinka monta

18 Salla: yhteensä (.) vạa

\section{Santtu: ei ole mont}

20

21 Santtu: joo. [(- - )

22 Saimi: [miten sä et oo ollu kommerssissa

$23 \quad(3.0)$

24 Villem: [ja: mit-

25 Salla: [meijän perhe käy joka vuos (.) mikä on se hiihtopaikka

26

27 Vaano: Otepää

28 Salla: Otepää joo

29 Vaano: mik:si. teil on: (0.4) Soomes ju palju paremad mäed

30

31 Salla: e:m $\uparrow$ mä tiä.

$32 \quad$ ((yhteistä naurua))

3 Käytetyt litterointimerkit ovat artikkelin lopussa. Käytän litteraateissani suomen ja viron ortografian mukaista merkintätapaa pyrkien valitsemaan merkintätavan käytössä olevan kielen perusteella. Kielten ainesten yhdistelystä johtuen valinta ei kuitenkaan aina ole yksiselitteinen. 
Villem aloittaa uuden topiikin rivillä 1 kysymällä suomalaisilta osallistujilta viroksi, miten monta kertaa he ovat aiemmin käyneet Virossa. Riveillä 6-14 Salla, Samuli ja Santtu vastaavat Villemin kysymykseen suomeksi. Santun vastaus (r. 14) saa muilta suomalaisilta ristiriitaisen vastaanoton: Saimin mielestä viisi kertaa on paljon (r. 15 ja 17) ja Sallan mielestä vähän (r. 18). Rivillä 19 Santtu yhtyy Sallan mielipiteeseen ja sanoo ei ole mont. Vuoro on sikäli mielenkiintoinen, että se on äännetty viron prosodiaa hyödyntäen, korkeammalta ja vähemmän monotonisesti kuin Santun muut vuorot. Vuoron kielellinen aines ei ole analysoitavissa vain toiseen kieleen kuuluvaksi: ei ole on sama suomeksi ja viroksi, ja kieltenvälinen ero piileekin juuri ääntämyksessä.

Rivin 19 vuoron todellinen kompromissimuoto on loppuheittoinen mont. Sanavartalo on selvästi suomea, ja se on kierrätetty aiemmista Sallan ja Saimin vuoroista, joissa se esiintyy yleiskielen mukaisessa montaasussaan (r. 2, 6, 15 ja 17). Loppuheittoinen asu ei olisi suomessa tavaton, mutta loppuheitolla Santtu tekee eron sanan aiempiin selvästi suomenkielisiin esiintymiin. Viron sananloppuisten ainesten kuluminen vaikuttaakin olevan suomalaisten tuntema viron kielen ominaispiirre ja loppuheitto suomalaisten osallistujien näkökulmasta keino tuottaa viroa oman äidinkielen pohjalta (ks. myös esim. 4).

Toisin kuin monissa seuraavista esimerkeistä, esimerkissä (1) sukukielten aineksia yhdistelevä vuoro ei ole reaktio vuorovaikutuksen ongelmaan. Itse asiassa esimerkin (1) vuorovaikutus on aineistossani poikkeuksellisen sujuvaa RM-vuorovaikutusta, jossa kukin osallistuja käyttää omaa äidinkieltään ja jossa kielten samankaltaisuus todella muodostaa "laajimman pohjan yhteiselle ymmärrykselle". Santun kielten aineksia yhdistelevällä vuorolla on siis jokin muu funktio kuin vuorovaikutuksen ongelman ratkaiseminen. Rivin 19 vuoro seuraa suomenkielistä keskustelua, jossa virolaiset ovat olleet vähän aikaa hiljaa. Santun vuoro voikin olla keino suunnata vuoro selkeämmin virolaisille osallistujille - kutsua heidät keskusteluun mukaan. Vuoro ei kuitenkaan saa aikaan erityistä reaktiota. Sitä ei kommentoida, eivätkä virolaiset osallistu keskusteluun vielä muutamaan vuoroon. 
Aineistossani esiintyy muutamia tällaisia lyhyitä vuoroja, jossa omaa äidinkieltä äännetään sukukielen prosodiaa jäljitellen. Useimmiten tätä keinoa käyttävät viroa aktiivisesti osaamattomat suomalaiset, ja se näyttää heille olevan keino tuottaa viroa. Tyypillistä sukukielen prosodiaa äidinkielen kielelliseen ainekseen yhdistäville vuoroille on se, että niillä ei pyritä ratkaisemaan vuorovaikutuksen ongelmia, vaan ne esiintyvät esimerkiksi topiikin päättävinä kommentteina. Pikemminkin niiden funktioksi voisi kuvata toisen kielen puhujien huomioon ottamisen sekä monikieliseen ryhmän olemassaolon ja siihen kuulumisen osoittamisen. Onkin todennäköistä, että kompromissirakenteilla on tarkastelemassani vuorovaikutuksessa muitakin funktioita kuin ymmärrettäväksi tekeminen, ja seuraavissa luvuissa palaan tähän ajatukseen.

\section{Kielten rakenteellisen samankaltaisuuden hyödyntäminen}

Skandinaavisten kielten puhujien välisessä RM-vuorovaikutuksessa kielten rakenteellisen samankaltaisuuden hyödyntäminen kompromissirakenteiden luomisessa ei saa Braunmüllerin (2002) tai Börestam Uhlmanin (1994) tutkimuksessa juuri huomiota. Börestam Uhlman (1994: 99) kuitenkin listaa toisenkielisen morfeemin lisäämisen omankieliseen sanavartaloon keinoksi muokata sanastoa sukukieliä vastaavammaksi. Suomalaisten ja virolaisten välisessä vuorovaikutuksessa näiden morfologisesti rikkaiden kielten rakenteellinen samankaltaisuus toimii kuitenkin selvästi yhteisesti ymmärrettävän rakentamisen resurssina. Kaivapalu ja Muikku-Werner (2010: 79-80, 86-87) esittävät, että sukukielen ymmärtämisprosessin kannalta viron ja suomen rakenteellinen samankaltaisuus on jopa yhtä tärkeä tekijä kuin sanaston yhtäläisyydet. Verschikin (2012) mukaan yhdenkielisen taivutusmorfeemin liittäminen toisenkieliseen sanavartaloon taas on keskeinen keino, jolla hänen informanttinsa pyrkivät tuottamaan toisen kielen puhujille ymmärrettäviä ilmauksia.

Aineistoni vuorovaikutuksessa tyypillinen tapa yhdistää kielten morfeemeja on liittää sukukielen taivutusmorfeemi äidinkielisen sanan 
sanavartaloon ja siten muodostaa enemmän toista kieltä muistuttava ilmaus. Esimerkissä (2) virolainen Vahur (5) rakentaa tällaisen kompromissimuodon käyttäen vironkielistä sanavartaloa ja suomenkielistä taivutusmorfeemia keskellä suomenkielistä puhettaan. Keskusteluun osallistuvat myös Villem (3) sekä Santtu (2) ja Sampo (1). Topiikkina on edellisen päivän myrsky, josta puhuminen alkaa hieman ennen katkelman alkua.

(2)

Vahur ja Santtu aloittavat keskustelun myrskystä suomeksi. Santtu on juuri kertonut sähköjen "menneen poikki” Suomessa.

01 Sampo: jaa mä en huomannut mitään

02 Santtu: 个aijaa. no ei siellä nyt varmaan ydinkeskustassa

03 Sampo: ei siellä mitään tuule

04 Santtu: niin (.) kaapelit menee maan alla

05 Sampo: $\mathrm{mm}$

06

07 Sampo: eikä tarvi olla ulkona

08 Santtu: niin

09

(3.0)

10 Vahur: on:k- miten itse asiassa Suomessa tämä krhm sähkövo- voimapuoli

11 on joten (0.2) että nyt kun Virossa:: on tämmönen megaprojekti

12 että (0.2) että halutan että että parin vuosin päästä on

13 kolmekymmentä prosenttia kaikista niistä sähkoja. ((2.4, jonka

14 aikana tekee voimajohtoja markkeeraavan eleen))kuinka se on

\section{Villiam: liinide}

16 Vahur: liineistä on menee maan alla. (0.6) mutta: kuinka onko Suomessa 17 Santtu: [mä-

18 Vahur: [myös tai näin tai onko teillä niin kuin

19 Santtu: mää [en-

20 Vahur: [enam- enamus ee niinkun ilmassa vai.

21 Santtu: mää en itse asiass osaa $>$ siitä niin tarkkaan sannom $m u t<$ sis

22 noista ( - - -) niin ne menee (0.4) sieltä valtakunnan halki

23 semmonen yks (.) runkoverkko iso semmonen linja (0.2) sit se

24 haarautuu isommiks

25 Vahur: jaa jaa (.) okei 
Esimerkin (2) riveillä 1-9 Sampo ja Santtu keskustelevat siitä, miksei Sampo ole huomannut sähkönjakelun heikkenemistä myrskyn seurauksena. Rivillä 4 Santtu ehdottaa syyksi sitä, että Sampon asuinalueella kaapelit menee maan alla. Rivillä 10 Vahur alkaa johdattaa sisään kysymystä siitä, kulkevatko voimalinjat Suomessa useammin maan alla vai päällä. Rivillä 13 Vahur pysähtyy hakemaan voimalinjoihin viittaavaa suomenkielistä sanaa, ja rivillä 15 Villem tulee apuun tarjoten ratkaisuksi vironkielistä sanamuotoa liinide 'johtojen'. Vahur ei kuitenkaan hyväksy tarjottua ainesta suoraan, vaan ikään kuin kääntää sanan suomeksi liittämällä suomenkielisen vartalovokaalin, monikon tunnuksen ja taivutuspäätteen tarjottuun vironkieliseen sanavartaloon (liin + eistä). Vahur integroi kompromissimuodon osaksi suomenkielistä vuoroaan ja käyttää sitä ratkaisuna ongelmaansa löytää suomenkielinen sana.

Esimerkissä (2) tämän strategian käyttö myös onnistuu - yhteinen ymmärrys syntyy joko kompromissimuodon avulla tai siitä huolimatta. Santtu ymmärtää Vahurin kysymyksen ja selvästi myös tunnistaa liinsanan linja-sanan vastineeksi. Aiemmin (r. 4) Santtu on käyttänyt maan alla kulkevista voimalinjoista kaapelit-sanaa, mutta rivillä 23 hän kierrättää linja-sanaa tarjoten runkoverkko-sanan selitykseksi lauseketta iso semmonen linja. Esimerkissä (5) ymmärtämisen voinee pääasiassa sanoa perustuvan käytössä olevaan yhteiseen koodiin (suomen kieli), mutta Vahur myös luo yhteistä koodia kielten aineksia yhdistelemällä.

Aina tällä tavoin rakennetun kompromissimuodon tarjoaminen ei kuitenkaan ratkaise vuorovaikutuksen ongelmaa. Esimerkissä (3) Valmar (3) pyrkii selittämään suomeksi Satulle (4) hauskaa juttua, josta Valmar ja Sarita ovat juuri puhuneet viroksi. Esimerkin (3) vuorovaikutuksessa ymmärtäminen alkaa kuitenkin murtua juuri kompromissimuotojen käytön seurauksena. Ennen katkelman alkua Valmar on ryhtynyt kuvailemaan Saritalle (5) internetistä löytämäänsä videota poliisiratsiasta, johon ajaa erittäin humalainen mies. Sarita ilmaisee tunnistavansa videon riveillä 3-4. Saritan ja Valmarin nauru ja elehdintä (r. 3-6) kiinnittävät tilanteessa läsnä olevan Satun huomion, ja rivillä 7 hän pyrkii mukaan keskusteluun vironkielisellä ymmärrysehdokkaallaan: siis mingi 
reklaam või 'siis jokin mainos vai'. Rivillä 9 Sarita vaihtaa kielen suomeksi, minkä jälkeen keskustelu jatkuu suomeksi riville 25 asti, jolloin Satu vaihtaa kielen taas viroon.

(3)

01 Valmar: ja siis talle löödi see masin kätte et vaadake et puhuge

02 nüüd siia ja vanamees võttis selle [kätte

03 Sarita:

[hah hah $\mathrm{j}(\mathrm{h}) \mathrm{oo}$

04 ma olen näind hah hah hah hah ((tekee juomiseleen))

05 Valmar: [((tekee juomiseleen)) heh heh [heh heh heh

06 Sarita: [((toistaa juomiseleen $))$ hahha [hah hah hah

07 Satu:

[siis mingi reklaam või

08 Valmar: [ei

09 Sarita: [e(h)ei e(h)i ei eik(h)u s(h)e oli ihan $t(h) o s i ~ j(h) u t t u h$

10 Satu: mitäh?

11 Valmar: hän oli niin juovuksissa että ei hän ymmärränyt mitä

12 hänen täyty tehtä.

13 Sarita: si[in oli niinku see

\section{Valmar: [että hän täyty puhua että muta}

15 Satu: aaa.=

16 Valmar: =se se oli ihan sellainen kun kun öö

17 Satu: [puhelin

18 Valmar: [plaskun kujulinen see (0.4) hän [oti sen-

19 Sarita:

[siis se: taskumatti

20 Satu: aaa

21 Valmar: oti sen apparaatin ja siis siis ((tekee juomiseleen))

22 Sarita: [eh heh heh [heh heh] hehe [heh heh heh hee hee

23 Satu:

[hah haa]

24 Valmar:

[he he he he he he he

25 Satu: aga voib olla et see olekski kasulik nagu et kui

26 sul on mingi selline väike pudel see taskumatti (0.4)

27 et siin olis mingid hälsignaalid $\mathrm{e}(\mathrm{h}) \mathrm{t}$ et saab

28 ajastada et iga igal tunni: järele vöi mingi poole tunni

29 järel et et et et tuleb mingi signaal et võta napsi

30 ((Sarita ja Valmar katsovat toisiaan, Valmar nyökkää.))

31 Sarita: ee ää või ära rohkem joo või ära enam

32 Satu: jah 
Rivillä 9 Sarita korjaa Satun käsityksen siitä, että puheenaiheena olisi mainos, muttei selitä, mistä on kyse. Saritan vuoro ei auta Satua muodostamaan käsitystä edellä puhutun sisällöstä, ja rivillä 10 Satu tuottaakin avoimen korjausaloitteen mitäh?, johon Valmar reagoi alkamalla kuvailla videon tapahtumia suomeksi (r. 11-12, 14). Valmar alkaa kertoa tarinaa ikään kuin sen keskeltä jättäen ymmärtämisen kannalta oleellisen taustoituksen pois; hän ei kerro, että taustatilanteena on poliisiratsia. Yhteistä tiedollista maaperää ei siis ole vielä saavutettu, kun Valmar rivillä 14 tuottaa vuoron että hän täyty puhua että muta. Suomeksi tuotettu vuoro sisältää sanamuodon puhua, jolla on suomessa eri merkitys kuin viron puhaltamista tarkoittavalla puhuda-sanalla.

Esimerkin (2) puhua-sanan voi analysoida suomen sanaksi, jolle Valmar on lainannut merkityksen virosta. Juuri ennen tarinankerronan alkua Sarita ja Valmar ovat kuitenkin leikkineet puhua- ja puhuda-sanojen merkityserolla, joten Valmar on tietoinen siitä, että näillä homonyymisillä sanavartaloilla on virossa ja suomessa eri merkitys. Valmarin vuoron sisältämän puhua-sanan voi analysoida myös kompromissirakenteeksi, jossa yhdistyy viron sanavartalo ja suomen $a$-infinitiivin tunnus. Oli kyseessä kumpi tahansa ilmiö, tuloksena on sekamuoto, joka aiheuttaa kieltenväliseen homonymiaan perustuvan ymmärtämisen ongelman. Valmarin tuottama puhua-sana on keskellä suomenkielistä vuoroa, ja Satu analysoi sen olevan suomea: hän tarjoaa rivillä ymmärrysehdokasta puhelin täydentämään Valmarin rivin 16 sanahakuun päättyvää vuoroa =se se oli ihan sellainen kun kun öö.

Päällekkäin Satun rivin 17 ymmärrysehdokkaan kanssa Valmar ratkaisee sanahakunsa lausekkeella plaskun kujulinen see 'taskumatin muotoinen se', joka on muodostettu toisaalta yhdistämällä viron sanavartalo suomen genetiivin päätteeseen ja toisaalta suomalaistamalla viron ne-loppuinen kujuline-sana suomen nen-loppuista sanatyyppiä vastaavaksi. Kompromissirakenne ei kuitenkaan auta yhteisen ymmärryksen syntymisessä. Satu ei välttämättä tunne sanoja plasku tai kujuline, minkä vuoksi kompromissimuodon rakentaminen näiden sanavartaloiden varaan ei tuota toivottua lopputulosta (ks. Satun rivillä 25 alkava 
vironkielinen vuoro, jossa hän vironkielisen taskumattia tarkoittavan sanan käyttämisen sijaan kuvailee taskumattia viroksi ja nimeää sen lopulta suomeksi: mingi selline väike pudel see taskumatti ‘jokin sellainen pieni pullo toi taskumatti').

Esimerkeissä (2) ja (3) viron ja suomen aineksia yhdisteleviä kompromissirakenteita käytetään ratkaisemaan sanahaku sukukieltä puhuttaessa. Verschikin (2012: 266) havaintojen mukaan kompromissimuotoja käytetään lähentämään kieliä toisiinsa, mutta tavoitteena ei ole toisen kielen puhuminen, vaan nimen omaan jonkinlaisen välimuodon tuottaminen. Omassa aineistossani kielten rakenteellista samankaltaisuutta kuitenkin selvästi käytetään myös toisen kielen tuottamisen resurssina.

Esimerkistä (4) on vaikea sanoa, pyritäänkö siinä tuottamaan sukukieltä vai jonkinlaista koko monikielisen ryhmän ymmärrettävissä olevaa sekakieltä. Siinä kuitenkin näkyy kiinnostavasti, millaisin eri tavoin rakenteellista samankaltaisuutta voi käyttää yhteisen koodin luomiseen. Siinä viroa jonkin verran opiskellut Sofia (3) yhdistää viron morfo-fonologisia piirteitä suomen- ja englanninkielisiin sanavartaloihin tuottaen kieltä, joka muistuttaa viroa. Esimerkissä (4) Sofia kysyy Virkiltä (1) tämän t-paitaa koskevan kysymyksen. Ennen katkelman alkua Virk, Valmar (3), Sauli (1) ja Sarita (5) ovat keskustelleet toisesta aiheesta englanniksi.

(4) ((Virkin paidassa lukee "Kiss the plumber"))

01 Sofia: tota (.) miks sa miks sa tahad plumberingaa musutada.

02 Virk: $\mathrm{m}(\mathrm{i}) \mathrm{s}$ :

03 Sofia: mi- (0.6)k sa tahad plumbergaa musutada

04 $(0.8)$

05 Sofia: sinum pạias sanoo et tahad plümbergaa músutada

06 Virk: aa. plumber

07 Sauli: $£$ musutataf heh [heh [heh

09 Sarita [eheh [heh heh he he

10 Sofia: [eh heh hehe

11 Valmar: torumehele $\mathfrak{E m u s i}$ teha£

12 Sarita: Emusi teha musi teha£

13 Virk: I guess I'm the plumber

14 Valter: eh heh heh 
Sofian rivin 1 kysymys on pääasiassa analysoitavissa viron kieleksi miks sa miks sa tahad plumberingaa musutada. Se kuitenkin sisältää sanamuodon plumberingaa, jossa yhdistyy ehkä jopa kolme kieltä: englanti, suomi ja viro. Plumber on äännetty suomalaisittain, ja siihen on liitetty suomen genetiivin tunnus - $n$ ja sidosvokaali $-i$. Lisäksi suomalaistettuun sanaan on liittynyt viron komitatiivin tunnus - $g a$ tai suomen puhekielen komitatiivinomainen kaa-kliitti. Virk ei ymmärrä rivin 1 kysymystä, ja hän tuottaa avoimen korjausaloitteen $m(i) s$ : 'mikä' (r. 2). Rivillä 3 Sofia toistaa kysymyksensä muokaten hybridimuotoa plumbergaa virolaisemmaksi, poistamalla siitä sen selvästi suomenkieliset ainekset.

Tätäkään vuoroa ei seuraa Virkin vastaus, ja pienen tauon jälkeen (0.8 s) Sofia ottaa taas vuoron ja lisää sinum paias sanoo et tahad plumbergaa musutada (r. 5). Rivin 5 vuoro on erityisen mielenkiintoinen, sillä siinä viron ja suomen ainekset yhdistyvät monella tapaa. Vuoron alun kehyslause sinum paias sanoo on rakennettu suomenkielisistä leksikaalisista aineksista, mutta sen rakenne on suomelle vieras. Sofia lieneekin muodostanut lausuman sen perustella, millaisen hän olettaa vironkielisen lause- ja sanarakenteen olevan. Vuoron mielenkiintoisin kompromissimuoto on paias. Siinä inessiivin tunnus on sekä viron että Sofian lounaisen kotimurteen mukaisessa loppuheittyneessä muodossa. Lisäksi astevaihtelu toteutuu sanassa muodossa, joka on tunnusmerkkinen Sofian kotimurteelle mutta kuulostaa jossain määrin virolta (vrt. vir. aed : aias 'aita; tarha'). Myös itse lauserakenne on ei-suomenmukainen, joskaan se ei ole suoranaisesti viroa (vrt. sinu särgil on kirjas). Rivin 5 vuoron kehyslause havainnollistaakin hyvin, miten yhteisen koodin tuottamiseen voi luovasti käyttää hyväkseen kontrastiivista tietämystä ja oletusta siitä, millaista toinen kieli voisi olla.

Lopulta Virk ymmärtää, mitä Sofia tarkoittaa ja tuottaa rivillä 6 ymmärtämistä ilmaisevan dialogipartikkelin aa sekä lausuu putkimiestä tarkoittavan sanan englanniksi ääntäen. Rivien 7-12 musutadasanaa käsittelevän välisekvenssin jälkeen Sofia ja Sarita alkavat nauraa (r. 9-10), ja naurullaan Sofia viimeistään merkitsee alkuperäisen kysymyksensä vitsiksi. Myös kielten ainesten yhdistelyllä vaikuttaa olevan 
muu funktio kuin ymmärrettävyyden parantaminen - kielten samankaltaisuudella leikkiminen ja ryhmän yhteisen kielen luominen. Lopulta Virk myös kuittaa vitsin ymmärretyksi sanomalla englanniksi I guess I'm the plumber, minkä jälkeen Valter nauraa (r. 13 ja 14).

Yhteistä edellä käsitellyille esimerkeille on ajatus siitä, että yhden kielen leksikaalisia aineksia voidaan yhdistää toisen kielen morfologiaan ja että tällä tavoin voidaan tuottaa toista kieltä lähempänä olevia kompromissirakenteita. Tavallisesti tätä keinoa käyttävät osallistujat, joilla on vähintään jonkinlainen toisen kielen taito eli tietämys toisen kielen morfologiasta. Kaivapalun ja Muikku-Wernerin (2010) havainto vaikuttaakin pitävän paikkansa: rakenteellinen samankaltaisuus tarjoaa keskeisen resurssin ymmärryksen rakentamiseen myös vuorovaikutuksessa. Yhteisen ymmärryksen synty ei kuitenkaan ole tällaisia kompromissimuotoja käytettäessä taattu, vaan kompromissimuotojen ymmärrettävyys riippuu muun muassa käytetyn sanavartalon tunnistettavuudesta ja sen mahdollisesta ambivalenttiudesta. Kuten esimerkki (4) osoittaa, kielten rakenteen samankaltaisuutta voi käyttää myös yhteisen leikin välineenä. Erityisen selvästi yhteinen leikki näkyy sanastotason ilmiöissä, joita käsittelen seuraavassa luvussa.

\section{Yhteistä sanastoa luomassa}

Börestam Uhlman (1994: 94-100) jakaa leksikaaliset keinot lähentää pohjoismaisia kieliä toisiinsa kolmeen kategoriaan. Ensimmäinen keino on käyttää kaikille kielille yhteisiä sanoja, jotka ovat puhujan äidinkielessä tunnusmerkkisiä synonyymeja tyylillisesti neutraalimmille sanoille, ja myös Braunmüller (2001) tarkastelee tunnusmerkkisten sanojen käyttönä mukauttamiskeinona. Toinen kategoria on "sanat, jotka eivät kuulu yhteenkään kielistä”. Siihen Börestam Uhlman laskee kuuluvaksi sekamuodosteet, jotka on luotu kielten aineksia sekoittamalla, esimerkiksi yhdistämällä yhden kielen sanavartalo ja toisen kielen morfeemi. Toinen kategoria sisältää myös merkitys- ja käännöslainojen käytön. Kolmas kategoria on uudismuodosteet, joihin kuuluvat 
puheessa spontaanisti syntyvät (yhdys)sanat. Ne eivät kuulu yhteenkään kieleen, mutta ne ovat kontekstin ja osiensa läpinäkyvyyden perusteella kaikille ymmärrettäviä.

Aineistossani esiintyy kaikkia edellä mainittuja ilmiöitä, mutta koska vuorovaikutuksen osallistujat eivät pitäydy omassa äidinkielessään, usein on vaikea sanoa, onko kyseessä esimerkiksi pyrkimys puhua toista kieltä vai tunnusmerkkisen synonyymin valitseminen, käännöslaina vai siirtovaikutus omasta äidinkielestä toiseen kieleen tai päinvastoin. Esimerkissä (5) ei voi tietää, onko Sofian vuorossa sana armas viroa vai tunnusmerkkistä suomea: vuoron muut lekseemit ovat suomenkielisiä, mutta Sakari-nimen päätteetön genetiivi viittaa siihen, että vuoron kohdekielenä saattaa olla myös viro.

01 Veijo: kule seal on raudselt on nagu: kaamera sees nagu ikkagi silmad 02 on nagu $=(($ osoittaa sohvan päällä olevaa nallea $))$

03 Sofia: =joo [(0.4) Sakari Sakari armas (.) nall:e

04 Valter: [heh heh heh heh heh heh

Esimerkin (6) riville 17 sijoittuvan Satun vuoron lekseemin ilmakitarr 'ilmakitara', viroksi ôhukitarr, voisi taas analysoida niin kieliä sekoittavaksi uudismuodosteeksi kuin siirtovaikutukseksi suomesta viroon. Yhteisen ymmärtämisen saavuttamisen kannalta on kuitenkin yhdentekevää, kumman kieliseksi ilmaus on tarkoitettu, jos merkitys on vuorovaikutuksen osallistujien näkökulmasta läpinäkyvä.

Sanaston yhtäläisyyksiä voidaan käyttää myös aktiivisesti ymmärryksen rakentamisen resurssina. Esimerkissä (6) Sarita (5) tarjoaa Sepolle (2) vironkielistä, suomea muistuttavaa sanaa ymmärtämisen avaimeksi. Juuri ennen katkelman alkua on keskusteltu oudoista suomalaisista urheilulajeista ja alettu pohtia, mitä lajeja kuuluisi "suomalaiseen kymmenotteluun”. Keskusteluun osallistuvat myös Valmar (3), Sauli (1), Satu (4) ja Vaadu (5). 
(6)

01 Valmar: sa- saunas käimine? siis on (0.4) öö kummiku vise? mobiili heide?

02 Sarita: ha $\mathrm{j}(\mathrm{h})$ ah [ha ha

03 Sauli: $\quad$ joo

04 Valmar: $\quad$ [sis soojalgpall?

05 Satu: [naise (.) kandmine

06 Valmar: [naise kandmine [häh häh häh

07 Sauli: [joo [kyllä

08 Sarita: [.hhhh jah

09 Valmar: mis siis veel on.

10 Vaadu: kärbse selle: või sääse või kärbse tapmine

11 Valmar: sää[se tapmine

12 Sarita: [sääse [sääse

13 Veijo: [s(h)ääse $t(h)$ apmine

14 Seppo: >se on (varmaa) niinku itikan<tappokisat.

15 Sauli: [j(h)oo k(h)yllä

16 Sarita: [joo siis sääsk

17 Satu: i- [ilma ]kitarri mängimine.

18 Seppo: [aijaa]

Esimerkin (6) kaksikielinen vuorovaikutus on melko sujuvaa: urheilulajeja luetteloidaan yhdessä käyttäen kumpaakin kieltä. Rivillä 14 Seppo kuitenkin tuottaa vuoron >se on (varmaa) niinku itikan<tappokisat., jonka Sarita tulkitsee osoitukseksi siitä, ettei Seppo välttämättä ole ymmärtänyt edellisissä vuoroissa (r.10-13) puhutun samasta urheilulajista viroksi. Rivillä 16 Sarita vahvistaa Sepon tulkinnan oikeaksi tarjoamalla selitykseksi vironkielistä sanaa sääsk 'hyttynen'. Sana muistuttaa suomen sanaa sääski, joka on paitsi tietynlaisten hyönteisten yleisnimitys myös hyttystä tarkoittava murresana. Huomionarvoista kuitenkin on se, että kumpaakin kieltä osaava Sarita tarjoaa sanaa viroksi eikä suomeksi. Oletuksena on se, että Seppo ymmärtää viron sanan sen samankaltaisuuden perusteella. Tyypillisesti leksikaalisten ainesten samankaltaisuutta ymmärtämisen mahdollistamiseen käyttävätkin molempia kieliä osaavat osallistujat. He pystyvät myös arvioimaan, mikä on leksikon 
samankaltaisuuden näkökulmasta kaikille ymmärrettävää, ja hyödyntämään tätä tietoa vuoroja rakentaessaan.

Leksikon samankaltaisuuteen tukeutuminen on melko ilmiselvä keino rakentaa yhteistä ymmärrystä. Kiinnostavampaa onkin se, että myös kieltenvälistä homonymiaa ja polysemiaa käytetään vuorovaikutuksen resurssina. Kielten sanaston näennäisellä samankaltaisuudella paitsi leikitään myös rakennetaan yhteyksiä kielten välille ja laajennetaan yhteistä koodia sanojen eri merkitystä käsittelevin merkitysneuvottelu- ja opetussekvenssein. Esimerkissä (7) kielten eri merkitysten välille vuorovaikutuksessa luotavalla kytköksellä todetaan yhteinen ymmärrys saavutetuksi. Ennen katkelman alkua Sakari (5), Sofia (3), Veijo (2) ja Valter (1) ovat keskustelleet opiskelijajärjestöjen välisen ystävyyssopimuksen solmimisesta leikilliseen sävyyn. Puheena on ollut se, ettei suomalaisella järjestöllä ole virolaista naisjärjestöä ystävänään, vaan vain miesjärjestö.

(7)

01 Sofia: ja aga o:nhan niil se daami (0.4) [kerho

02 Veijo: [aa daamide klubi on meil jah

03 Sofia: daamide klubi

((Poistettu Sakarin ja Valterin vironkielinen välisekvenssi (r. 4-8), jossa vitsaillaan samasta aiheesta.))

09 Sofia: onko ne daamit kaikki varattuja.

10 Sakari: tavaliselt küll sest nad on siis Rotalia\#:[:\# > kellegi-<

11 Sofia:

[个eikö siinä voi

12 olla Rotalia ja s:inkku daami klubi.

13 Sakari: eh heh heh heh heh [he he

14 Valter: [Rotalia sinkku.

15 Sofia: jah

16 Valter: mis se sink on eh heh

17 ((Valmar, joka ei ole osallistunut mihinkään meneillään olevista

18 keskusteluista, alkaa nojautua eteenpäin))

19 Sofia: nii siis s- single

20 Veijo: a $\uparrow h[$ aa joo joo

21 Valter: [ha hah hah [hah 
22 Sofia:

23 Valter:

24

25 Veijo: [vapaa- vapaat [(naiset)

[hah hah hah see

\section{Valmar: sinkku se on se on vaba kinkku}

((Sofia, Sakari, Valter ja Veijo nauravat))

Esimerkin (7) alussa Sofia ottaa puheeksi virolaisen ystävyysjärjestön naistenkerhon, johon kuuluu järjestön jäsenten kumppaneita. Rivillä 9 Sofia esittää kysymyksen, onko ne daamit kaikki varattuja, johon Sakari alkaa vastata viroksi. Päällekkäin Sakarin vuoron kanssa (r. 11-12) Sofia jatkaa kuitenkin vitsiään kysymällä $\uparrow$ eikö siinä voi olla Rotalia ja s:inkku daami klubi. Osallistujista vain Sakari kohtelee Sofian vuoroa vitsinä, nauraen sille rivillä 13. Rivillä 14 Valter tuottaa korjausaloitteen Rotalia sinkku ja kohdentaa rivin 16 vuorollaan ymmärtämisen ongelmansa kysyen, mis se sink on 'mikä se kinkku on', ja naurahtaa vuoron lopuksi. Rivillä 16 Valter ilmaisee, mihin viron sanaan hän itselleen tuntemattoman sinkku-sanan assosioi, mutta vuoron lopun nauru paljastaa, ettei hän täysin vakavissaan tulkitse samankaltaisia sanoja samanmerkityksisiksi. Zeevaert (2007: 108) huomauttaakin, että RM-vuorovaikutuksessa homonyymisista ja polyseemisistä sanoista vain kontekstiin sopiva merkitys aktivoituu, mikä useimmiten ehkäisee väärinymmärryksen syntyä. Esimerkissä (7) konteksti rajoittaakin toisen kielen mukaista tulkintaa tehokkaammin kuin esimerkin (3) konteksti, jossa ymmärtämisen ongelman lähteenä on kontekstiin paremmin sopiva puhu-vartalo.

Viron mukainen 'kinkku'-merkitys kuitenkin avautuu Valterin vuorosta, ja keskusteluista syrjässä ollut Valmar alkaa nojautua kohti muita osallistujia, ja saatuaan vihdoin vuoron sanoo rivillä 27 sinkku se on vaba kinkku. Yhteinen ymmärrys on jo saavutettu rivin 19 Sofian englanninkielisen käännöksen avulla (niin siis single), johon Veijo ja Valter reagoivat sekä osoittaen ymmärtäneensä sekä sisällön että vitsin (r. 20-25 nauru ja kommentointi). Valmar kuitenkin vielä selittää suomen sinkkusanan merkityksen käyttäen viron sink-sanan merkitystä selityksensä 
pohjana. Selitys ei ole Sofian vitsin ymmärtämisen kannalta välttämätön, ja Valmarin vuoro toimiikin omana vitsinään, joka kierrättää edellä esillä olleiden, muodoltaan samankaltaisiksi havaittujen sinkku- ja sinksanojen merkitykset ja luo niiden välille semanttisen suhteen.

Valmarin vuoro on paitsi kielten samankaltaisuudella leikittelevä vitsi myös esimerkki siitä, miten kummankin kielen merkitykset ovat vuorovaikutuksessa jatkuvasti läsnä. Muodoltaan samankaltaisten leksikaalisten ainesten merkityksiä vertaillaan toistuvasti keskenään, ja osallistujat voivat ottaa eri kielten merkitykset osaksi yhteistä koodia. Vuorovaikutuksessa niin kutsutuille väärille ystäville voidaan siis rakentaa merkitys, jossa yhdistyy kummankin kielen semantiikkaa, ja näin kieliä voidaan myös tuoda lähemmäs toisiaan. Kielipeleillä myös osoitetaan yhteisen monikielisen koodin tuntemusta, ja kieltenväliseen homonymiaan ja polysemiaan perustuvien vitsien tehtäväksi voisi usein kuvata myös monikielisen ryhmäidentiteetin vahvistamisen.

Kielten sanastojen samankaltaisuus toimii siis vuorovaikutuksen resurssina monella tapaa. Se tarjoaa etenkin kumpaakin kieltä osaaville osallistujille mahdollisuuden rakentaa vuoronsa valiten sanansa sen mukaan, minkä he arvioivat olevan ryhmän muiden jäsenten ymmärrettävissä. Kielten sanaston näennäinen samankaltaisuus voi kuitenkin aiheuttaa myös ymmärtämisen ongelmia, aivan kuten Kaivapalu ja Muikku-Werner (2010) testitulostensa perusteella raportoivat. Toisaalta sanaston näennäisestä samankaltaisuudesta ollaan hyvin tietoisia, ja kieltenvälistä samankaltaisuutta käytetään kielelliseen leikittelyyn ja yhteisen koodin luomiseen.

\section{Lopuksi}

Vaikka viro ja suomi eivät ole yhtä läheisiä sukukieliä kuin esimerkiksi skandinaaviset kielet, kielten samankaltaisuus tarjoaa vankan pohjan yhteisen ymmärryksen rakentamiselle virolais-suomalaisessa RM-vuorovaikutuksessa. Kumpaa tahansa kieltä voi tarjota ymmärrettäväksi, ja toista kieltä voi ymmärtää oman äidinkielen pohjalta. 
Kielten samankaltaisuutta voidaan käyttää myös aktiivisesti hyödyksi kaikille osallistujille ymmärrettävien ilmausten rakentamiseen. Tarkastelemani vuorovaikutuksen osallistujille kielten samankaltaisuus tarjoaa ajatuksen siitä, että omaa äidinkieltä muokkaamalla ja kielten aineksia yhdistämällä voi tuottaa toista kieltä tai sitä lähempänä olevia ilmauksia. Osallistujat hyödyntävät kummankin kielen tarjoamia resursseja luodakseen yhteistä koodia, joka voi olla kielten standardivarianttien väliin sijoittuva kompromissi, tai jonka kohteena voi olla toinen kieli.

Kielten äänteellisiä, morfologisia ja leksikaalisia aineksia yhdistelemällä voidaan pyrkiä ratkaisemaan vuorovaikutuksen ongelma, mutta kompromissirakenteet voivat toimia myös ymmärtämisen ongelman lähteinä. Kielten todellisen samankaltaisuuden ei voikaan katsoa olevan vuorovaikutuksen osallistujien käytössä suoraan, vaan osallistujat tekevät tulkintoja ja muotoilevat puheensa nojaten havaitsemaansa ja olettamaansa samankaltaisuuteen sekä metalingvistiseen tietoisuuteen kielten yhtäläisyyksistä ja eroista (ks. esim. Kaivapalu \& Muikku-Werner 2010; Ringbom 2007: 7, 24-25; Verschik 2012: 271-272). Kielten ainesten yhdistämisen vuorovaikutuksessa mahdollistaakin jonkinlainen kielitietoon perustuva ja/tai vuorovaikutuksessa syntyvä käyttöhypoteesi siitä, millaista toinen kieli on, mikä kielissä on samanlaista ja millainen suhde kielten aineksilla on toisiinsa (ks. myös Rehbein ym. 2012: 4).

Kompromissimuodot tuovat kuitenkin kiinnostavasti esiin sen, millaisen kielellisen aineksen osallistujat olettavat olevan toisen kielen puhujille ymmärrettävää, ja myös kielten keskinäinen ymmärrettävyys nousee neuvottelun kohteeksi näiden kielten aineksia yhdistelevien rakenteiden kautta. Kielten eksplisiittinen vertailu on keskustelun topiikkina toistuvasti, ja osallistujat vaikuttavat olevan hyvin tietoisia paitsi siitä, että kielillä on paljon vastaavuuksia, myös siitä, että aina samankaltaisillakaan aineksilla ei ole kielissä samaa merkitystä. Kielten näennäinen samankaltaisuuskin toimii ryhmän yhteisen koodin luomisen resurssina, ja viime kädessä merkitykset rakennetaan ryhmän vuorovaikutuksessa. Kielten vertailua koskevat jaksot, joissa metalingvistinen 
tietoisuus nousee keskustelun pintaan, ovatkin kiinnostava jatkotutkimuksen aihe.

Tarkastelemassani vuorovaikutuksessa kummankin kielen aineksia yhdistelevät vuorot voivat olla osa täysin sujuvaa monikielistä vuorovaikutusta. Kompromissivuorojen funktio ei aina näytä edes olevan ymmärrettävyyden parantaminen, vaan kielten samankaltaisuutta käytetään myös esimerkiksi yhteisen kielellisen leikittelyn ja monikielisen ryhmän ryhmäidentiteetin vahvistamisen resurssina. Toisin kuin Verschikin (2012) aineistossa, tarkastelemassani aineistossa suomalaisten ja virolaisten välillä ei ole epäsymmetriaa sen suhteen, kuinka paljon tai miten kielten samankaltaisuutta käytetään vuorovaikutuksen resurssina. Erot vaikuttavat pikemminkin johtuvan erilaisista yksilöllisistä tekijöistä, kuten toisen kielen tuntemuksesta, ja Verschikin aineiston epäsymmetria selittyneekin vuorovaikutuksen osallistujien institutionaalisten roolien (myyjä ja asiakas) epäsymmetrisyydellä.

Tarkastelemani vuorovaikutus eroaa myös aiemmin tutkitusta skandinaavisten kielten puhujien välisestä RM-vuorovaikutuksesta. Aineistoni on lähtökohdiltaan hyvin samanlainen kuin Börestam Uhlmanin (1994): arkivuorovaikutusta toisilleen tuttujen ihmisten välillä. Aineistot poikkeavat toisistaan ennen kaikkea kielivalinnoiltaan. Börestam Uhlmanin aineistossa suurin osa vuoroista on tuotettu kunkin puhujan äidinkielellä, kun taas omassa aineistossani kielet valikoituvat muun muassa kulloisenkin puhujan ja vastaanottajien kielitaidon mukaan. Myös eri kielten yhdistely saman vuoron sisällä on virolaisten ja suomalaisten välisessä vuorovaikutuksessa yleisempää kuin skandinaavisten kielten puhujien välisessä.

Aineistojen väliset erot johtunevat monesta syystä. Ensinnäkin skandinaaviset kielet ovat keskenään läheisempiä kuin viro ja suomi ja luovat siten laajemman pohjan keskinäiselle ymmärrettävyydelle. Lisäksi skandinaavisten kielten puhujien välillä RM on vakiintunut ja laajasti tunnettu vuorovaikutustapa (kielipolitiikan merkityksestä RM:n valintaan vuorovaikutuksen tavaksi ks. esim. Zeevaert \& ten Thije 2007). Toisaalta myös tämän tutkimuksen kohteena olevassa sosiaalisessa verkostossa 
RM:llä on erityinen status, mikä varmasti tukee suomen ja viron käyttöä englannin sijaan tai rinnalla. Kiinnostava jatkotutkimuksen aihe onkin tarkastelemani vuorovaikutuksen kielivalinnat ja niiden syyt.

\section{Litterointimerkit}

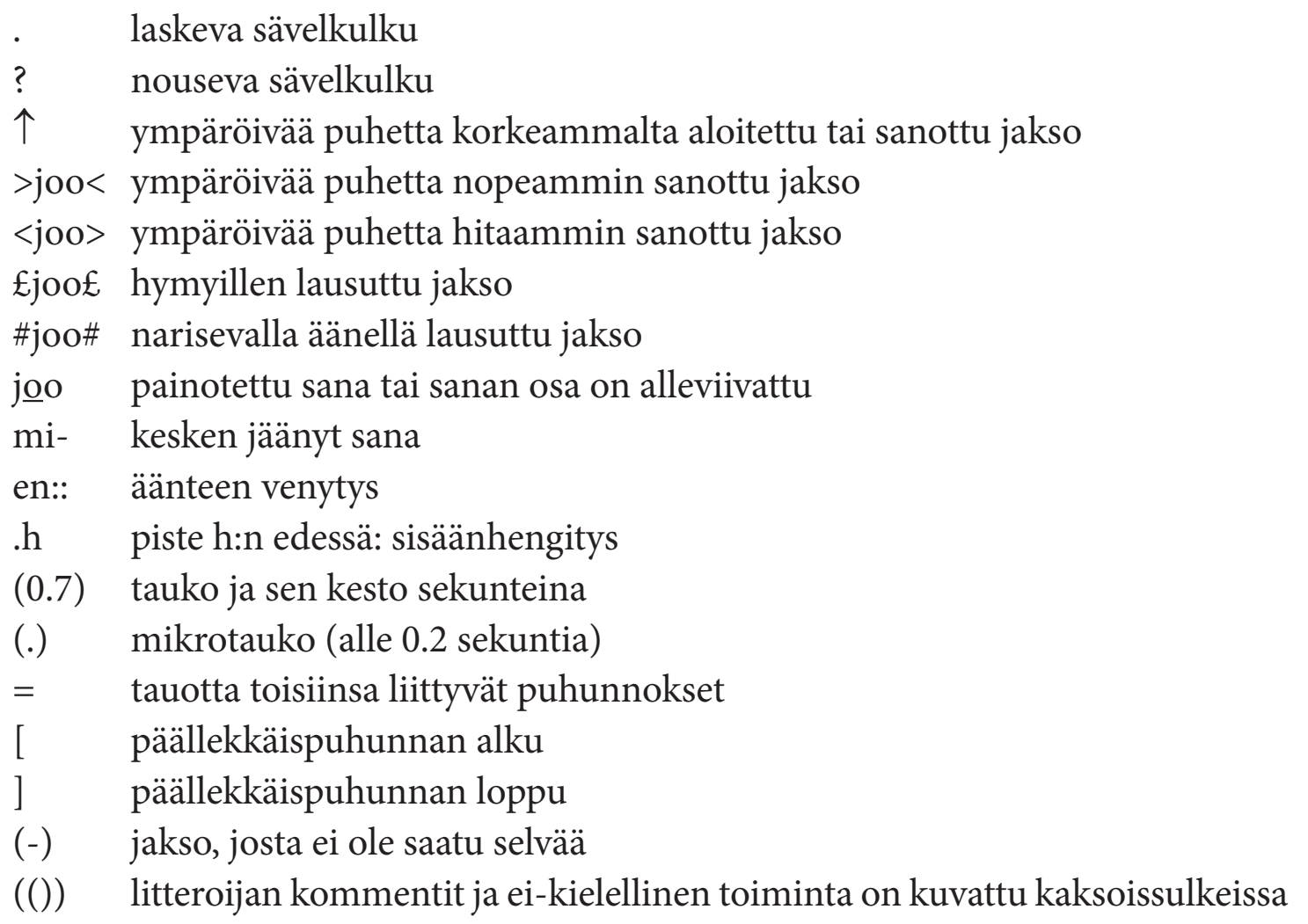

\section{Lähteet}

Bahtina, Daria, Jan D. ten Thije 2012. Receptive multilingualism. - Carol A. Chapelle (Ed.). The Encyclopedia of Applied Linguistics. Oxford: John Wiley and Sons.

Bezoojen, Renee van, Charlotte Gooskens 2007. Interlingual text comprehension. Linguistic and extralinguistic determinants. - Jan D. ten Thije, Ludger Zeevaert (Eds.). Receptive Multilingualism. Linguistic Analyses, Language Policies and Dialectic Concepts. Amsterdam: John Benjamins, 249-263.

Braunmüller, Kurt 2002. Semicommunication and accommodation: Observations from the linguistic situation in Scandinavia. - International Journal of Applied Linguistics 12 (1), 1-23. http://dx.doi.org/10.1111/1473-4192.00022 
Braunmüller, Kurt, Ludger Zeevaert 2001. Semikommunikation, rezeptive Mehrsprachigkeit und verwandte Phänomene. Eine bibliographische Bestandaufnahme. Arbeiten zur Mehrsprachigkeit, Folge B 19. Hamburg: Universität Hamburg, Sonderforschungsbereich Mehrsprachigkeit.

Börestam Uhlmann, Ulla 1994. Skandinaver samtalar. Språkliga och interaktionella strategier i samtal mellan danskar, norrmän och svenskar. Uppsala: Institutionen för nordiska språk vid Uppsala universitet.

Giles, Howard, Justine Coupland, Nikolas Coupland 1991. Accommodation theory: Communication, context, and consequence. - Howard Giles, Justine Coupland, Nikolas Coupland (Eds.). Contexts of Accommodation. New York, NY: Cambridge University Press, 1-68.

Härmävaara, Hanna-Ilona 2009. Vokaalien keston variaatio virolaismuuttajien puheessa. Julkaisematon pro gradu -tutkielma. Helsingin yliopisto.

Härmävaara, Hanna-Ilona (tulossa). Facilitating mutual understanding in everyday interaction between Finns and Estonians. - Receptive Multilingualism. Special issue of Applied Linguistics Review.

Junttila, Jaakko 2006. “Koomista lasten kieltä”. Jyväskyläläisten ja tarttolaisten opiskelijoiden asenteista sukukieleen. - Annekatrin Kaivapalu, Külvi Pruuli (Toim.). Lähivertailuja 17. Jyväskylä Studies in Humanities 53. Jyväskylä: Jyväskylän yliopisto, 137-154.

Kaivapalu, Annekatrin, Pirkko Muikku-Werner 2010. Reseptiivinen monikielisyys: miten suomenkielinen oppija ymmärtää viroa äidinkielensä pohjalta? - Lähivõrdlusi. Lähivertailuja 20, 68-95. http://dx.doi.org/10.5128/ $\underline{\text { LV20.03 }}$

Rehbein, Jochen, Jan D. ten Thije, Anna Verschik 2012. Lingua receptiva (LaRa) Remarks on the quintessence of receptive multilingualism. - Jan D. ten Thije, Jochen Rehbein, Anna Verschik (Eds.). Receptive Multilingualism. Special Issue of International Journal of Bilingualism, 248-264. http:// dx.doi.org/10.1177/1367006911426466

Ringbom, Håkan 2007. Cross-Linguistic Similarity in Foreign Language Learning. Second Language Acquisition 21. Clevedon: Multilingual Matters.

Verschik, Anna 2012. Practicing receptive multilingualism: Estonian-Finnish communication in Tallinn. - Jan D. ten Thije, Jochen Rehbein, Anna Verschik (Eds.). Receptive Multilingualism. Special Issue of International Journal of Bilingualism, 265-289. http://dx.doi.org/10.1177/1367006911426465

Zeevaert, Ludger 2007. Receptive multilingualism and inter-Scandinavian semicommunication. - Jan D. ten Thije, Ludger Zeevaert (Eds.). Receptive 
Multilingualism. Linguistic Analyses, Language Policies and Dialectic Concepts. Amsterdam: John Benjamins, 103-136.

Zeevaert, Ludger, Jan D. ten Thije 2007. Introduction. - Jan D. ten Thije, Ludger Zeevaert (Eds.). Receptive Multilingualism. Linguistic Analyses, Language Policies and Dialectic Concepts. Amsterdam: John Benjamins, 1-21.

\section{Hanna-Ilona Härmävaara}

Suomen kielen, suomalais-ugrilaisten ja pohjoismaisten kielten ja kirjallisuuksien laitos

PL 3 00014 Helsingin yliopisto, Finland hanna-ilona.harmavaara@helsinki.fi 


\title{
Cross-linguistic similarities as a resource of multilingual interaction between Finns and Estonians
}

\author{
HANNA-ILONA H ÄRM ÄVAARA \\ University of Helsinki
}

This article discusses how the cross-linguistic similarities between Finnish and Estonian are used as a resource of interaction between Finns and Estonians that belong to a social network in which using both languages is a common way of communication. The data of the study consist of video-recorded informal conversations that are conducted in Finnish and Estonian. The data are analyzed within the framework of conversation analysis.

The studied interaction can be called receptive multilingualism (RM). RM is a language constellation in which interactants employ a language different from their interlocutor's language and understand each other mostly without the help of any additional lingua franca (cf. Zeevaert \& ten Thije 2007; Rehbein et al. 2012). In the case of closely related languages, the understanding is based on mutual intelligibility of the languages. Between non-related or remotely related languages RM interaction can succeed if the participants have at least some proficiency in the other language (see Zeevaert 2007).

Even though Finnish and Estonian are quite closely related languages, they cannot be seen effortlessly comprehensible for the speakers of the other language because of the differences e.g. in their vocabulary. As evidenced in the previous research (Härmävaara, forthcoming), in the observed data mutual understanding between the speakers of these cognate languages is based both on the similarities of the languages and the means by which the mutual understanding is ensured, such as different kinds of translatory actions and multilingual negotiations of meaning.

In the data, also the (assumedly) similar elements of the languages are used as a resource of creating mutual understanding. The participants with at least some degree of knowledge or idea of the other language can design their speech to this multilingual group by e.g. combining phonological, lexical and morphological elements of these structurally very similar cognate languages through 
approximating what would be comprehensible for all group members (cf. Verschik 2012).

Sometimes these multilingual forms create, rather than solve, problems in the interaction, and the meaning of these in-between forms has to be negotiated. Also the mutual intelligibility of the languages is constantly being negotiated through these multilingual forms, varying from slight accommodation of pronunciation to creating vocabulary and larger constructions that combine elements of both languages. Additionally, the similarities of the languages are used as a resource of creating multilingual group identity.

Keywords: receptive multilingualism; conversation analysis; mutual intelligibility between cognate languages; adjoining languages; accommodation; group identity 